\title{
Critical aspects of phytoalexins in potato
}

\author{
STURE BRISHAMMAR \\ Department of Plant and Forest Protection, The Swedish University of Agricultural Sciences, \\ P.O. Box 7044, S-750 07 UPPSALA, Sweden
}

\begin{abstract}
Phytoalexins in potato are sesquiterpenoid substances produced in response to infections and are believed to help plants resist attack by pathogens. However, these compounds appear in response to compatible as well as incompatible interactions and only accumulate in the tubers. The amounts of phytoalexins produced depend on the physiological condition of the tubers. Young tubers don't get easily infected with Phytophthora infestans even though they synthesize extremely small amounts of phytoalexins. Furthermore, confusion as to the identity of specific races and the propensity for a given race to produce different effects in the same type of host makes it extremely difficult to predict host-parasite interactions with any acceptable degree of accuracy. It is doubtful that the production of phytoalexins in response to artificial inoculations is representative of that occurring in natural infections. Markedly different types of pathogens induce synthesis of same substances in the host cells. It therefore seems most probable that all the phytoalexins are synthesized in response to stimulation by an endogenous elicitor. Little knowledge is available regarding the biosynthesis of these sesquiterpenes, and many previous determinations have presumably been erroneous. When potato tubers were inoculated with the late blight fungus, secondarily appearing bacteria were not retarded, despite the presence of phytoalexins. There is no generally accepted hypothesis describing the mechanism by which phytoalexins inhibit pathogens and no distinction has been made between the effects on necrotrophs and biotrophs. Adequate bioassays capable of measuring the effects of inhibition have yet to be developed, thus far, no convincing inhibitory effects have been reported. During purification of the phytoalexins there is a high risk for artifact forming, implying that specific compounds cannot be detected with certainty. Moreover, present analytical methods must be improved before we can determine how phytoalexins act in vivo. Probably, phytoalexins are synthesized at a stage in the infection too late to be able to restrict its expansion with the tissues of the host. Phytoalexins are restricted to the attacked parts of the tubers and there is no evidence indicating that these compounds pose any health risks when present in potatoes used fqr consumption.
\end{abstract}

Index words: potato, tuber, phytoalexins, sesquiterpenes, elicitation, bioassays, purification, detection

\section{Introduction}

From the turn of this century until the be- ginning of World War II, plant pathologists showed a notable interest in induced resistance in plants. They presumed that plants had an 
immunological system similar to that of higher animals. Although most researchers considered the occurrence of circulating antibodies to be highly improbable, many of them were looking for proteins that, like antibodies, are capable of binding pathogens (CHESTER 1933). Meanwhile, other scientists regarded the tannins as the antibodies of plants (MEYER 1939).

Against this background we will consider the postulate formulated by MÚLLER and BörGER in 1940, based on their experiments on locally induced resistance in potato tubers following inoculations with Phytophthora infestans (Müller and Börger 1940). After inoculations with avirulent races on tuber cross-sections exposed by slicing, an 'effect of immunization' was obtained - i.e., the preventively treated surfaces resisted attack by virulent races. It was thereby assumed that defensive substances - so-called 'phytoalexins' - were produced in response to the first infection.

More than one and a half decades later, when beans were examined instead of potato tubers, Múller (1956) regarded the phytoalexins as antibiotics synthesized when host plant tissues respond to pathogen infections by forming local lesions. His view had somewhat altered, since he now proposed that phytoalexins even take part in defending against the primarily infecting fungus.

TоміуамA et al. (1968) isolated the sesquiterpene rishitin from potato tubers after inoculation with $P$. infestans, and subsequently, this substance and some other closely related sesquiterpenes have generally been considered to be synonymous with the hypothetical phytoalexins in potato, postulated by MÜLLER and BÖrger (1940). Gradually, however, definitions of phytoalexins became increasingly generalized until a wide variety of substances with real or assumed inhibitory effects against microorganisms were regarded as phytoalexins.

Due to this confusion, attempts were made by a large number of researchers to agree on a stringent definition. One was consequently formulated as follows: 'Phytoalexins are low molecular weight antimicrobial compounds that are both synthesized by and accumulated in plants after their exposure to microorganisms' (Paxton 1981).

Some scientists consider the production of phytoalexins as a consequence, not a cause, of plant resistance to infection (KIRÁLY et al. 1972), but current opinions basically support the view that phytoalexins are part of the resistance mechanism of plants against pathogens and that they act through direct contact with these pathogens. Still, it has yet to be unequivocally proved that substances with the above-mentioned qualities actually exist.

\section{Experimental material}

In general, a resistance reaction resulting in a hypersensitive response has been associated with the generation of phytoalexins. After studying the experimental material in its entirety, however, I can find no basis for this assumption. For example, very few proper investigations of phytoalexin production in leaves have been performed (Kuć 1982, RoHWER et al. 1987) even though infections of $P$. infestans are mostly initiated in the haulm.

There is an obvious difference between green parts of the plant and storage tissues e.g. potato tubers. The green cells of leaves have photosynthetically produced energy at their disposal, while the more isolated tubers are dependent on the degradation of starch stores for energy. Thus there is a pronounced difference in the availability of energy between green leaves and tubers, and this difference can increase under stress conditions. In green, photosynthesizing cells all metabolic pathways seem to be continuously active; therefore, the turnover of sesquiterpenes is presumably also more steady, implying that no real accumulation of such substances will occur.

The physiological state of the tubers is of great importance in determining how much of and how fast the various phytoalexins are synthesized and transformed once the tubers become infected. Tuber condition is in turn 
dependent on environmental variables - e.g. soil quality, water availability and fertilization. Storage conditions - e.g. temperature, humidity and light will also affect tuber physiology.

The period between harvest and infection must also be considered. It is well-known that freshly harvested tubers produce little or no phytoalexins when inoculated; nevertheless, they are more resistant than physiologically aged tubers (BHATIA and Young 1985). Moreover, the amounts of phytoalexins obtained with compatible and incompatible races of $P$. infestans do not differ when young tubers are infected (Brishammar et al. 1987).

The method used for inoculation also affects the way in which the metabolism is activated. An attack on the periderm differs in character from an attack on the pith. Tuber varieties may differ in their degree of sensitivity and resistance within their various tissue regions. In cv 'Grata', for example, the skin is relatively resistant to fungal attack while the pulp of the tuber is very sensitive. In contrast, other varieties generally show less pronounced differences in this respect.

Consequently, interactions may differ, depending on whether the fungus is inoculated through a bored hole in the tuber (and with the core, reintroduced afterwards) (HoRIKAwA et al. 1976), or spread on the cut surface of a tuber cross section (Tоміуама et al. 1968).

Boring - and especially sectioning - are drastic disturbances, causing severe reactions in the affected tissues. Hydrolyzing enzymes are released from the cracked lysosomes (WILSON 1973), and large amounts of carbon dioxide evaporate from the exposed tuber surfaces (KAHL 1974). The reconstruction of destroyed units involves a considerable resynthesis of individual molecules as well as complex cellular structures. These energydemanding activities require an accelerated rate of starch degradation, simultaneously with an activation of glycolysis and the pentose shunt (KaHL 1974). Furthermore, the citric acid cycle is switched on, thereby leading to the opening of synthetic routes for the forma- tion of fatty acids and terpenoids (KAHL 1974).

Cutting, for instance, involves the activation of tuber tissues in a way that presumably does not occur during spontaneous, natural infections, in which the production of sesquiterpenes is delayed compared with production following laboratory inoculations preceded by a sectioning procedure.

The pulp consists of a variety of tissues (REEve et al. 1969) that each react at a characteristic rate when a tuber is cut. Thus the peripheral tissues react faster than the interior ones - i.e., maximum respiration is attained in the cortex cells after one day while it takes 2 days to reach a maximum in the pith cells (KAHL 1974). A sample of infected material taken as a 1-mm slice below the inoculated surface across the tuber therefore comprises a series of divergent tissue cells that are out of phase with each other regarding the biosynthesis of sesquiterpenes.

For these reasons it is doubtful that laboratory experiments can simulate the conditions associated with natural infections while simultaneously obtaining enough homogeneous sample material to undertake a chemical analysis of phytoalexins using techniques available at present. Likewise, it is probable that the cutting of potato tubers and similar manipulations alter the characteristics of the surface exposed to pathogens during infections. Consequently, under artificial conditions the interactions between host and compatible and incompatible races of pathogens such as $P$. infestans can be expected to differ from interactions occurring in natural infections.

\section{The pathogen}

Races of $P$. infestans used for inoculating tubers to induce production of phytoalexins were initially classified based on the symptoms induced on the leaves of test plants, representing an assortment of potato varieties (BLACK et al. 1953). Since leaf and tuber tissues can react differently, an incompatible 
reaction on a leaf does not ensure that the same type of response will occur in corresponding tubers. Consequently, race determinations should be carried out on tubers as well as leaves.

It is also generally taken for granted that in inoculation assays, test plants exhibit an all-or-nothing response, irrespective of the size of the plants. However, uncertain 'transitional' symptoms probably occur, in which case they would complicate the readings and race determinations. It is also conceivable that a given variety of potato could react differently between locations and tests. Any latent viral infection in a test plant will affect the reading, and the risk for such infections can never be excluded. Thus an absolute race determination is probably not possible with this methodology.

Races of late blight fungus also tend to change with time. Thus it is conceivable that their features differ to some extent during the course of an experimental period. As a consequence, isolates should be submitted for recurrent testing to confirm their racial identity.

$P$. infestans can induce various levels of phytoalexins in the same tuber variety, depending on the pathogen race involved (BRISHAMmar et al. 1987). On the other hand, a specific isolate can vary in its effects from occasion to occasion depending on its physiological condition - e.g., its ability to absorb amino acids. To explain differential resistance to various fungal races, it might be more rewarding to determine differences in their essential-nutrient needs and in their ability to utilize such nutrients instead of using the conventional approach of defining compatible and incompatible races (FAULL and CASSELTON 1984).

Finally, it should be added that laboratory inoculations with pure races may differ in character from spontaneous infections, in which several races probably occur simultaneously. In natural infections, it is also likely that the infecting fungus is accompanied by contaminating microorganisms such as bacteria.

\section{Turnover of sesquiterpenes in potato tubers}

When the sesquiterpene rishitin was first isolated in infected tubers (Томіуама et al. 1968) - and since it was thought to have antifungal activity (TоміуAмA et al. 1968) it was therefore not surprising that rishitin was proposed as the hypothetical phytoalexin of potato (Múller and Börger 1940). That rishitin, in particular, was designated as a phytoalexin may simply have been a consequence of the analytical technique used, which emphasized sesquiterpenes. If other categories of substances had been under analytical consideration, other types of compounds would most certainly also have been regarded as phytoalexins of potato.

The most recently accepted definition of phytoalexins (PAXTON 1981) states that such substances must accumulate at infection sites; such accumulations are deemed necessary for detecting these compound with present-day analytical methods. Still, the question remains as to whether an accumulation of phytoalexins occurs specifically in response to infections or if other factors (not directly related to an infection) can induce accumulations. It must also be proved that the tentatively determined phytoalexins actually take part in the plant's defence against pathogens.

In which tissues and to what extent are phytoalexins present in uninfected cells? Rishitin and phytuberin could not be detected in extracts of potato leaves that had been inoculated with incompatible or compatible races of P. infestans (Kuć 1972, RoHwER et al. 1987). In sprouts, an accumulation of rishitin only occurred in connection with compatible interactions between the sprouts and $P$. infestans (VARns et al. 1971).

Sesquiterpenoid substances similar to or even exactly resembling the phytoalexins in potato tubers have been detected in the leaves of other members of the Solanaceae (e.g. tobacco and tomato), but it is uncertain as to whether these compounds were synthesized in response to infections (KUC 1972, TAKAGI et al. 1979). 
Various amounts of rishitin and closely related sesquiterpenes have also been found in healthy tubers of certain potato varieties (Kuć et al. 1976, Schöber 1978, Brishammar et al. 1987), indicating that not all phytoalexin production is dependent on infections (KuĆ et al. 1976).

According to Müller and Börger (1940) phytoalexins should be end-products, but a number of researchers (Mural et al. 1977, WARD 1977) do not regard the formation of rishitin as the last step in the proposed biosynthetic sequence. Mural et al. (1977) suggested that in cells with undisturbed metabolism, rishitin is transformed into two new compounds (rishitin-M-1 and rishitin-M-2), which are then further transformed into watersoluble forms. There are, however, no data to support hypotheses describing the final catabolic sequence, and degradation into $\mathrm{C}_{5}$-compounds has never been observed.

Added rishitin can probably be metabolized by cells in which all metabolic pathways are activated - as in photosynthesizing cells or tuber cells with an activated citric acid cycle (KAHL 1974). Thus cut tubers that have been permitted to age should be able to metabolize rishitin in contrast to freshly sectioned tubers (IsHiguri et al. 1978).

Thus the biosynthetic pathway responsible for the production of rishitin and related sesquiterpenes may actually operate in a variety of healthy tissues in both leaves and tubers. If true, then such a pathway should be possible to detect if the sensitivity of current analytical techniques can be improved.

The accumulation of rishitin and associated metabolites in connection with infection may either indicate that a certain function of the cell needs an extra stimulus to counteract the attacking pathogen or that the cells are in an early stage of decline, leading to necrosis.

In contrast to higher animals, plants are devoid of centralized excretory organs, consequently, the individual cells have to eliminate their own waste products to prevent them from contacting the actively metabolizing cell units (SitTe 1974). Limited amounts of sesquiterpenes can probably be detoxified by normal cells, but when present in great excess, phytoalexins and other similar compounds have to be transferred to adjacent, necrotic cells, which thereby provide a waste storage function.

In suspensions of potato tuber cells infected with $P$. infestans the cells synthesize phytoalexins, which then diffuse out into the nutrient solution (Brinde et al. 1983). This indicates that rishitin becomes an end product - possibly a waste product - when the cells are metabolically overloaded.

There are indications that rishitin can counteract the growth stimulating effects induced by additions of indole acetic acid (Tоміу Ama et al. 1968). Rishitin can also inhibit the germination of Solanum pollen (HodGIN and LyON 1979). These observations suggest that rishitin and possibly other so-called phytoalexins function primarily as cell-regulatory substances rather than as pathogen inhibitors. It should be noted that the sesquiterpenoid plant hormone abscisic acid can accumulate in response to wilting (W AIN 1977). Consequently, the anti-pathogenic activity of the phytoalexins is perhaps only coincidental.

As is true for all sesquiterpenes, potato phytoalexins are derived from farnesyl pyrophosphate (FPP) (CORDELL 1976); moreover, all of the phytoalexins seem to be synthesized within the same part of the sesquiterpenoid pathway. After FPP, rishitin and phytuberin presumably have at least one precursor - a germacrene - in common (Stoessl 1982). In the sequence leading to rishitin, the various steps are not yet known in detail. Still there is good agreement that solavetivone, lubimin and rishitin are synthesized in chronological order, although there may be some other steps in-between (Stoessl 1982).

Experience has shown that it is technically difficult to conduct in vivo studies of sesquiterpenoid biosynthesis in higher plants 
based on the incorporation of suspected precursors (BAKER and BrooKs 1976). Transport barriers, compartmentation effects, rapid catabolism of the desired products and consumption of precursors by more competitive biosynthetic pathways all contribute to the reduced incorporation of assumed precursors (BAKER and Brooks 1976). Moreover, the sesquiterpenes have very complex, threedimensional structures (StOEssL et al. 1976); thus it is hard to obtain sufficient amounts of uniform material.

In this treatment of phytoalexin biosynthesis and accumulation the occurrence of sesquiterpene glycosides has been ignored. However, such a compound has been demonstrated in potato tubers infected with Phoma exigua var foveata, and its aglycone is closely related to solavetivone (MAlmberg and TheAnder 1980). Also four similar sesquiterpene glycosides have been isolated from healthy tobacco leaves after flue-curing (ANDERSON et al. 1977).

In studies of biosynthesis using a radioactive precursor $\left({ }^{14} \mathrm{C}\right.$-labelled mevalonate), a substantial degree of radioactivity was incorporated into terpenoid glycosides (FrANCIS and O'Connel 1969, Banthorpe et al. 1972). Thus sesquiterpene glycosides probably occur more frequently within the 'phytoalexin-pathway' than previously believed. The glycosides are more hydrophilic than the phytoalexins; thus, the former may have eluded discovery, since when isolating phytoalexins, all extractions have been performed with hydrophobic solvents. Furthermore, the glycosidic linkages may be enzymatically broken by the action of glycosidases, which are released during homogenization.

The fact that the sesquiterpene glycoside detected in potato tubers (MALMBERG and THEANDER 1980) has an aglycone that is closely akin to solavetivone suggests that the glycoside occurs at a comparatively early stage during the biosynthesis and therefore may not be in a state of decline. Instead, the glycosides may actually be the functional forms of the sesquiterpenoid phytoalexins.

\section{The course of infection and the production of phytoalexins}

The phytoalexins are regarded to have broad-spectrum activity and may be synthesized in response to infections by a number of pathogens. In the course of a late blight infection phytoalexin production apparently does not occur during spore germination, germ tube growth, or development of the appressorium. Not until the infection peg has penetrated the tissues, does an elicitor act upon the host cell membrane. The fungus then develops a haustorium, which is an indentation of the host cell's plasmalemma. At that time $P$. infestans is at a biotrophic stage. If the infected cell and adjacent cells subsequently begin to produce phytoalexins, and if these compounds really have anti-pathogenic properties, then they will either have to act directly against the fungus at very low concentrations outside the host cell, or act indirectly, regulating host cells in such a way as to render them less accessible to the attacking fungus.

There is no evidence to date that phytoalexins accumulate before the onset of necrosis. It should also be stressed that pathogens that develop haustoria are not very susceptible to direct-acting anti-microbial substances (SCHÖNBECK and SCHLÖSSER 1976).

Changes over time during the infection by an incompatible race of $P$. infestans have been followed using microscopical examinations (SATo et al. 1971, Jones et al. 1975 a, Jones et al. 1975 b). The primarily infected host cell generally dies after $3-4 \mathrm{~h}$, while the incipient formation of rishitin was first detected 10$11 \mathrm{~h}$ after inoculation, in cut tubers that had been allowed to age for $15 \mathrm{~h}$ before being infected (SATo et al. 1971).

Cell death and accumulation of phytoalexins occur later in association with compatible interactions than in association with incompatible ones. As previously mentioned, phytoalexin production should start off slower in natural infections than in artificial infections, since spontaneous infections are not preceded by 
the metabolic activation resulting from the cutting of tubers.

In pathogens inducing phytoalexin synthesis in host cells the course of infection will vary, depending on pathogen type. Therefore it is doubtful that inhibitory mechanisms are the same in different types of interactions. Still, we do not know if there are any differences in the stage at which and mechanisms by which phytoalexins inhibit a hemi-biotroph such as $P$. infestans and a necrotroph such as Phoma exigua. If inhibition occurs during the necrotrophic stage of a pathogen within the host plant, then direct contact can occur between the fungus and the phytoalexins, and it should be possible to clearly register the effect in bioassays in vitro. If this scenario is valid, then phytoalexins are probably not involved in defending against biotrophs, since necrosis occurs prior to the synthesis of these substances, and the biotrophs will die in dead or dying cells because of their complete dependence on the intact metabolism of the host cells. If, on the other hand, phytoalexins contribute to the inhibition of pathogen development when the host cells are still intact and phytoalexin concentrations are very low, then they would most likely act as cell activity regulators, inducing disease resistant mechanisms in the cells. Unfortunately, it is doubtful that present analytical techniques are sensitive enough to reveal differences between infected and healthy cells, since only minute amounts are present.

\section{Elicitation}

Higher and lower fungi and bacteria (LyON et al. 1975) apparently elicit formation of the same kinds of phytoalexins in infections of potato tubers and other plant species. Phenolic phytoalexins also have been detected in plants after attacks by necrotizing viruses (KLARMAN and Hammerschlag 1972), which can elicit synthesis of sesquiterpenes in tobacco leaves in the same way (BAILEY et al. 1976). Thus it appears as if widely differing categories of pathogens can induce synthesis of the same types of compounds. Is there one type of elicitor common to all pathogens or do a variety of elicitors exist that each use a different mechanism to induce the same type of host cell biosynthesis? It seems most likely that in all cases an endogenous elicitor is released from the wall of the host cell (HARGREAvES and BAILEY 1978) in response to pathogen attack - irrespective of pathogen type. The endogenous elicitor may be a saccharide that reacts with a specific receptor, probably a lectin (Garas and Kuć 1981), located in the plasma membrane of the tuber cell. It is already known that small amounts of rishitin are present in healthy tubers after cutting. The cutting procedure sets lysosomes free in the tissues, and their enzymes may degrade constituents of the cell wall (RAY 1972), making the endogenous elicitor available.

The sesquiterpenoid phytoalexins accumulate after infections, in association with both compatible and incompatible interactions, but the accumulation occurs faster and to a greater extent in the latter case (Kuć 1982). Even then, potato tubers treated with sonicated mycelium of $P$. infestans develop necroses and accumulations of phytoalexins, but the responses are exactly the same regardless as to whether virulent or avirulent races are used (VARnS et al. 1971). Two fatty acids, eicosapentanoic and arachidonic acid, detected in the mycelium of $P$. infestans, have been proved to induce synthesis of phytoalexins in potato tubers (Bоsтоск et al. 1981). Their effects, however, may be nonspecific, and they probably act by interfering with the lipoid parts of the host cell membrane, thereby impairing their function (LODE and PEDERSEN 1970). Since these two fatty acids are also found in the cell wall of the late blight fungus, it is also possible that treatment with sonicated mycelium elicits nonspecific reactions as well. Sonicates and cell wall preparations of other fungi or heat-treated bacteria, however, do not induce accumulations of phytoalexins (Kuć et al. 1984), suggesting that these organisms are devoid of the two fatty acids. If this is the case, then the substances of current in- 
terest are probably not of universal occurrence; consequently, they should not serve as specific elicitors. Instead, the evidence suggests that in cases where attacks by necrotizing viruses are accompanied by the formation of phytoalexins, an endogenous elicitor is involved (Klarman and Hammerschlag 1972), Bailey et al. 1976).

It can therefore be assumed that all pathogens penetrating the host cell wall cause the endogenous elicitor to be released. Compatible races, however, may competitively inhibit bonding between the endogenous elicitor and the specific receptor by emitting glycans functioning as suppressors (DOKE et al. 1979). This is in accordance with the theory that resistance is normal while sensitivity is abnormal (INGRAm 1978).

To emit suppressors, a compatible race must remain undisturbed during the infection process. Additions of chloramphenicol or streptomycin at the time of inoculation of potato tubers with virulent races of $P$. infestans consequently result in hypersensitive reactions - i.e., early necrosis formation and accumulation of phytoalexins, two symptoms of incompatible interactions (KIRALy et al. 1972). It is also conceivable that virulent races can be influenced by other types of additions associated with artificial infections, causing the pattern of infection to deviate from that characteristic of spontaneous, natural infections.

\section{Bioassays}

The new definition of phytoalexins (PAXTON 1981) does not set any concentration limits above which activity is attributed to non-phytoalexin-related effects. Nor does it refer to how antimicrobial activity shall be measured. Moreover, there is no generally agreed upon procedure for estimating the ability of phytoalexins to inhibit pathogens.

There are considerable difficulties involved in the design of an in vitro bioassay to test for antipathogenic activity, since the results may not reflect the actual in vivo situation. Of the many studies on phytoalexin occurrence only a few deal with their antipathogenic activity, and, on the whole, there are no firm conceptions to how and when inhibition occurs.

Phytoalexins must act during a stage when their formation is in phase with the growth of the attacking fungus. It is hardly relevant to study inhibition of spore germination (Hargreaves and Mansfield 1975, Doke et al. 1979) or germ tube growth (DOKE et al. 1979), since, to all appearances, the production of phytoalexins does not begin until the infection peg has penetrated the membrane of the host cell. Furthermore, inhibitory activity should be assayed with an actual pathogenic fungus such as $P$. infestans. Obviously, it is also necessary to test both compatible and incompatible races. Thus little would be gained by using a non-pathogenic fungus such as Cladosporium sp. (Hargreaves and MANSFIELd 1975).

It is very doubtful whether phytoalexins such as rishitin function as inhibitors of spore germination. For example, the established endogenous inhibitor methyl-3,4-dimethoxycis-cinnamate in the spores of the crown rust fungus (МАско et al. 1972) is about $10^{7}$ times more inhibitory than rishitin.

Furthermore, the inhibitory activity of phytoalexins in in vitro bioassays is at least one hundred times lower than that of the fungicide metalaxyl when used against the late blight fungus (BRISHAMmar and WIDMARK 1987). Furthermore, they are no better at inhibiting pathogens than certain other sesquiterpenes, that are quite irrelevant in this connection (BRISHAMMAR and WIDMARK 1987). It should also be added that the inhibition achieved in these bioassays is not complete. Accordingly there are no distinct demarcation zones between the fungus and the added phytoalexins; such zones are characteristic of bioassays with certain bacterial isolates and the fungus or with conventional antibiotics against bacteria.

There are also disagreements in the literature concerning the inhibitory ability of the various phytoalexins. Many researchers ob- 
served inhibition with rishitin and - to a lesser extent - with lubimin, but not with solavetivone. However, other workers consider solavetivone to be the most active compound (STÖSSEL and HoHL 1981, BRISHAMMAR and WIDMARK 1987).

Estimates as to the amounts of specific phytoalexins required to inhibit fungal growth vary greatly. Generally, the necessary doses are very high (HARris and DenNIS 1976, SмIтH 1982), although there are some exceptions (WARD et al. 1974). LyON and BAYLESS (1975) consider phytuberin to be ineffective against bacteria, and according to HARRIS and DenNIS (1976) this phytoalexin is even devoid of fungitoxic and fungistatic activity.

The variation in inhibitory activity between studies may be due to differences in purity. There is an obvious risk that sesquiterpenes can be contaminated with fatty acids and methyl esters of fatty acids, which may inhibit growth of the fungus (LiNDEBERG and LiNDEBERG 1974). Furthermore, it is probable that the sensitive, three-dimensional structures of the sesquiterpenes can be easily disturbed. Therefore the configuration of any particular phytoalexin may actually differ from one preparation to another.

Some researchers consider phytoalexins to be ineffective against primary pathogens (KIRÁly et al. 1972) while inhibiting subsequent secondary microorganisms (VAN DER Plank 1975). In experiments on interactions between potato tubers and the late blight fungus, however, the secondary bacterial pathogens were not inhibited (Brishammar et al. 1987).

Concrete suggestions as to the mechanisms of the supposed inhibition by phytoalexins are lacking apart from an interesting hypothesis by Stössel and HoHL (1981). They proposed that solavetivone acts as an inhibitor of glucanases, which are secreted by certain fungi, including $P$. infestans. However, it is presumably not possible to detect this type of inhibitory activity on fungi in vitro on an agar medium. In addition, it is doubtful that the phytoalexin can reach inhibitory concentra- tions in vivo quickly enough to catch the fungus at its susceptible stage.

As inhibitors of pathogenic fungi the various sesquiterpenoid phytoalexins seem to be inferior to a number of phenolic substances (Malmberg et al. 1980). It is also doubtful that hydrophobic compounds such as sesquiterpenes come into direct contact with a fungus restricted to a hydrophilic environment. Conceivably, glycosidic forms (MALMBERG and THEANDER 1980), which are more water-soluble, could have more inhibitory activity.

\section{Preparation, separation and detection}

The quality of the sample material is of particular importance when isolating sesquiterpenoids. It may also be difficult to minimize heterogeneity in samples, which generally consist of a mixture of dead cells, cells in various degrees of decline and healthy cells. Although the use of cut (infected) tubers allows samples to be taken in very thin, even layers, the sample slices comprise (as mentioned earlier) a variety of tissues whose biosyntheses are out of phase with each other.

In infections established deep in the tuber pulp - e.g. those occurring after artificial inoculation or those associated with rots it is difficult to exclusively isolate the tissues of interest. Such problems can occur when, for example, the concentrations of rishitin are to be determined at various times after infection. In killed cells the amounts of rishitin should remain constant, although some rishitin is lost owing to problems involved in the extraction of sesquiterpenoid substances from wilted tissues. Furthermore, the extraction procedure itself may induce decomposition or other molecular changes, thereby decreasing actual yields. If living cells producing relatively large amounts of phytoalexins recover after the stress induced by the forced synthesis, it is probable that the rishitin produced will be catabolized and decay. The markedly different estimates of rishitin life expectancy within the 
cells (Kuć 1972, Murai et al. 1977, Ward et al. 1977, Brishammar et al. 1987) may stem from variation in the relative proportions of killed and living cells between samples. In this respect the choice of tuber variety may play an important rôle.

The formation and occurrence of phytoalexins seem to be markedly restricted to infected areas. In association with compatible reactions, however, the phytoalexins appear deeper in the tubers, since accumulations are formed in connection with the expansion of the infection (SCHÖBER 1980). On the other hand, any reports of large amounts of sesquiterpenoid phytoalexins deep in tubers after incompatible interactions are certainly incorrect and probably are the result of detection error. It should be noted that during gas chromatography, the methyl esters of the fatty acids mostly turn up in the same region as the sesquiterpenes (Coxon et al. 1977).

The method of extraction and choice of solvent may partly determine the types and amounts of the sesquiterpenes recovered (StOESsL et al. 1976). Moreover, if samples are used in which cell sesquiterpene biosyntheses are not synchronized, the variety of compounds produced may be great. These substances may then be further modified by secondary microorganisms.

During purification of sesquiterpenes, in particular, there is a risk that the extraction will give rise to artifacts (KUĆ 1982, WICKBERG 1983). Such compounds generally do not exist in nature, either in living or in dead tissues. Slight structural shifts in the three-dimensional molecular pattern would probably render a compound biologically inefficient. Consequently, sesquiterpenes that are active in vivo may show little or no activity after being isolated from tissues (WICKBERG 1983).

The type of methods used for identifying and quantitating plant constituents can have a definitive impact on the results. For instance, it is unadvisable to exclusively base sesquiterpene determinations on one system of thin layer chromatography, even if reference substances are used. Not even gas chromatog- raphy can alone provide reliable qualitative and quantitative results, especially when packed columns are utilized. Capillary columns definitely permit better separation of substances; nevertheless, confirmation of results by mass spectrometry or other methods is necessary, since more than one compound can have the same retention time.

The general use of hydrophobic, organic solvents for purification of sesquiterpenoid phytoalexins has led to a de-emphasis on the identification of water-soluble types, such as sesquiterpene glycosides (MALMBerG and TheANDER 1980). Thus it is very likely that more types of glycosides would be discovered if a systematic search for such compounds was undertaken. For instance, the HS-toxin, which is produced by Helminthosporium saccari, has been shown to be a glycoside with a sesquiterpene as an aglycone to which four hexoses are bound, forming the active unit (MАСKo 1983).

\section{Toxicity}

Can phytoalexins in potato tubers cause toxic reactions when the tubers are used as food or forage? Since these sesquiterpenes lack any appreciable fungitoxic effects, there is little apparent risk for toxicity in either humans or animals. Furthermore, phytoalexins are generally restricted to the attacked parts of the tubers, which are usually small unless the infection expands.

Neither the substances of current interest nor closely related ones are included in the international index, 'RотесS' (1980), treating toxic compounds. Moreover, no harmful effects were noted when mice were exposed to phytuberin (RENWICK 1972), and no embryotoxic or teratogenic effects appeared when pregnant mice were exposed to either rishitin or phytuberin (NEUdECKER and SCHÖBER 1984). Mammals are probably also capable of synthesizing glycosides of terpenes, which are then excreted (Ishag 1984).

Certain injurious effects have been observed in plants after exposure to sesquiterpenoid phy- 
toalexins (SMITH 1982). For instance, rishitin can cause membrane injuries (LYON 1980) resembling those produced by some fatty acids (Lode and Pedersen 1970). However, very high concentrations of phytoalexins are usually required to cause such adverse reactions, and it is therefore uncertain as to whether they actually occur in nature.

\section{Conclusions}

It is generally accepted that phytoalexins of potato are sesquiterpenes. These substances only accumulate in tubers in response to infections. In fact, there is no comprehensive picture regarding the turnover of these sesquiterpenes in the tuber and haulm. Thus no information is available on the role of sesquiterpenoid glycosides in cells, although these compounds may be important. The general conception that phytoalexins in potato are sesquiterpenes may have developed by accident. Phenolics, fatty acids, analogs of amino acids, peptides, etc. could presumably have been regarded as phytoalexins as well.

Phytoalexins are considered to be unspecific inhibitors with a direct impact on pathogens. However, no general mechanism of inhibition has been established, nor are there any methods available for measuring the extent of inhibition. Data has yet to be obtained on in vivo concentrations of phytoalexins in micro-sites harboring developing pathogens (Deverall 1976), and the forms of the sesquiterpenes active on these sites remain unidentified. It is also very doubtful that the phytoalexins are produced in time to prevent pathogen growth (DALY 1972) - in fact the pathogen and the phytoalexins may actually never meet in vivo!

It is conceivable that phytoalexin synthesis is always induced by means of an endogenous elicitor released from the cell wall of the host when penetrated by microorganisms. Compatible interactions, however, may indicate that the endogenous elicitor was not able to reach its receptor, which may have been occupied by so-called suppressors (DOKE et al. 1979) emitted by the pathogen.

Phytoalexin deposits are definitely restricted to the infection sites and appear in connection with cell death. Consequently, accumulations of phytoalexins turn up earlier in association with incompatible interactions than in association with compatible ones.

It is difficult to determine whether the inhibitory ability of a metabolite in vitro actually reflects its activity in vivo. Inhibition obtained with phytoalexins has been limited and may also have been accidental (STOESSL 1980). From an energetic point of view, it seems 'uneconomical' for the plant to exert resistance through directly operating inhibitors of this kind. However, it is conceivable that phytoalexins or closely related metabolites could serve as regulators, stimulating host cells to defend themselves against pathogens by preventing pathogen entrance through modifications of the spatial patterns of the structural molecules, by withdrawing essential nutrients or by producing nutrient types - e.g., amino acids, that can be utilized by the host cells but not by the pathogens (FAull and CASSELTON 1984).

No differences have yet been documented in phytoalexin content between potato tubers affected by compatible interactions and those affected by incompatible reactions.

During the initial stages of pathogen development, when the pathogens appear on the superficial parts of the plants, pathogen growth is probably retarded through contact with individual inhibitory substances, most or all of which originate from microorganisms in the phyllo- and rhizospheres. Otherwise, direct-acting anti-microbial substances should not be assumed to exist until it is possible to unambiguously demonstrate that host cells really produce compounds capable of inhibiting pathogens in vivo at very low concentrations.

The designation of the term 'phytoalexin', in connection with a hypothesis (MüLLER and 
Börger 1940), has led to a host of preconceptions, that have introduced serious bias into related studies on plant defense against pathogens.

\section{References}

Anderson, R., Gunn, D.M., Murray-Rust, J., Murray, P. \& Roberts, J.S. 1977. Vetispirane sesquiterpene glucosides from flue-cured Virginia tobacco: Structure, absolute sterio-chemistry and synthesis. X-ray structure of the p-bromobenzenesulphonate of one of the derived aglycones. J. C. S. Chem. Commun. 27-28.

Balley, J.A., Vincent, G.G. \& Burden, R.S. 1976. The antifungal activity of glutinosone and capsidiol and their accumulation in virus-infected tobacco species. Physiol. Plant Path. 8: 35-41.

BAKER, F.C. \& Brooks, C.J.W. 1976. Biosynthesis of the sesquiterpenoid capsidiol in sweet pepper fruits inoculated with fungal spores. Phytochemistry 15: 689-694.

Banthorpe, D.V., Le Patourel, G.N.J. \& Frances, M.J.O. 1972. Biosynthesis of geraniol and nerol and their $\beta$-D-glucosides in Pelargonium graveolens and Rosa dilecta. Biochem. J. 130: 1045-1054.

Bhatia, S.K. \& Young, R.J. 1985. Reaction of potato tuber slices to Phytophthora infestans in relation to physiological age. Am. Potato J. 62: 471-476.

Black, W., Mastenbroek, C., Mills, W.R. \& Peterson, L.C. 1953. A proposal for an international nomenclature of races of Phytophthora infestans and genes controlling immunity in Solanum demissum derivates. Euphytica 2: 173-179.

Bostock, R.M., Kuć, J. \& Laine, R.A. 1981. Eicosapentaenoic and arachidonic acids from Phytophthora infestans elicit fungitoxic sesquiterpenes in potato. Science 212: 67-69.

Brindie, P.H., Kuhn, P.J. \& Threlfall, D.R. 1983. Accumulation of phytoalexins in potato-cell suspension cultures. Phytochemistry 68: 2719-2721.

Brishammar, S., Helmersson, S., Widmark, A.-K. \& Berggren, B. 1987. Analysis of sesquiterpenoid phytoalexins in potato tubers. (to be published).

Brishammar, S. \& Widmark, A.-K. 1987. Bioassays of sesquiterpenoid phytoalexins in vitro. (to be published).

Burden, R.S., Bailey, J.A. \& Vincent, G.S. 1975. Glutinosone, a new antifungal sesquiterpene from Nicotiana glutinosa infected with tobacco mosaic virus. Phytochemistry 14: 221-223.

Chester, K.S. 1933. The problem of acquired physiological immunity in plants. Quart. Rev. Biology 8: $129-154,275-324$.

Cordell, G. 1976. Biosynthesis of sesquiterpenes. Chemical Reviews 76: 425-460.

Coxon, D.T., Price, K.R., Howard, B. \& Curtis, R.F.
Acknowledgements. Thanks are due to Dr. David Tilles for correcting the English. Financial support was obtained from the Swedish Council for Forestry and Agricultural Research.

1977. Metabolites from microbially infected potato. Part. 1. Structure of phytuberin. J. Chem. Soc. Perkin Transactions I, Part 1: 53-59.

Daly, J.M. 1972. The use of near-isogenic lines in biochemical studies of the resistance of wheat to stem rust. Phytopathology 62: 392-400.

Deverall, J. 1976. Current perspectives in research on phytoalexins. In: Friend, J. \& Threlfall, D.R., Eds., Biochemical aspects of plant-parasite relationships. Ann. Proc. Phytochem. Soc., 13. Academic Press, NY, pp. 208-224.

Deverall, B.J. 1982. The concept of phytoalexins. In: Bailey, J.A. \& Mansfield, J.W., Eds., Phytoalexins. Blackie, Glasgow and London, pp. 1-20.

Doke, N., Garas, N.A. \& Kuć, J. 1979. Partial characterization and aspects of the mode of action of a hypersensitivity-inhibiting factor (HIF) from Phytophthora infestans. Physiol. Plant Path. 15: 127-140.

Francis, M.J.O. \& O'Connel, M. 1969. The incorporation of mevalonic acid into rose petals. Phytochemistry 8: 1705-1708.

Faull, J. \& Casselton, P. 1984. Pathogen nutrition during the saprophytic phase of Phytophthora infestans infection of potato. Bull. British Mycolog. Soc., supplem. 2: 8 .

Garas, N.A. \& Kuć, J. 1981. Potato lectin lyses zoospores of Phytophthora infestans and precipitates elicitors of terpenoid accumulation produced by the fungus. Physiol. Plant Path. 18: 227-237.

Hargreaves, J.A. \& Mansfield, J.W. 1975. Phytoalexin production by Vicia faba in response to infection by Botrytis. Ann. Appl. Biol. 81: 271-276.

Hargreaves, J.A. \& Balley, J.A. 1978. Phytoalexin production by hypocotyls of Phaseolus vulgaris in response to constitutive metabolites released by damaged cells. Physiol. Plant Path. 13: 89-100.

Harris, J.E. \& Dennis, C. 1976. Antifungal activity of post-infectional metabolites from potato tubers. Physiol. Plant Path. 9: 155-165.

Hodgin, T. \& Lyon, G.D. 1979. Inhibition of Solanum pollen germination in vitro by the phytoalexin rishitin. Ann. Bot. 44: 253-255.

Horikawa, T., Tomiyama, K. \& Doke, N. 1976. Accumulation and transformation of rishitin and lubimin in potato tuber tissue infected by an incompatible race of Phytophthora infestans. Phytopathology 66: 11861191.

INGRAM, D.S. 1978. Cell death and resistance to biotrophs. 
Ann. Appl. Biol. 89: 291-295.

IsHaG, K.E.A. 1984. Mono- and sesquiterpene alcohol glucosides - synthesis and characterization. Ph. D. Diss., Mathematisch-Naturwissenschaftlichen Fakultăt der Universität der Saarlands, Saarbrücken, BRD.

Ishiguri, Y., Tomiyama, K., Doke, N., Mural, A., Katsui, N., Yagihashi, F. \& Masamune, T. 1978. Induction of rishitin-metabolizing activity in potato tuber tissue disks by wounding and identification of rishitin metabolites. Phytopathology 68: 720-725.

Jones, D.R., Graham, W.G. \& Ward, E.W.B. 1975. Ultra-structural changes in pepper cells in an incompatible interaction with Phytophthora infestans. Phytopathology 65: $1274-1285$.

Jones, D.R., Unwin, C.H. \& WARD, E.W.B. 1975. The significance of capsidiol induction in pepper fruit during an incompatible interaction with Phytophthora infestans. Phytopathology 65: 1286-1288.

KAHL, G. 1974. Metabolism in plant storage tissue slices. The Botanical Rev. 40: 263-314.

KirÁly, Z., BARnA, B. \& ErSEK, T. 1972. Hypersensitivity as a consequence, not a cause, of plant resistance to infection. Nature 239: 456-458.

Klarman, W.L. \& Hammerschlag, F. 1972. Production of the phytoalexin, hydroxyphaseollin, in soybean leaves inoculated with tobacco necrosis virus. Phytopathology 62 : 719-721.

Kuć, J. 1972. Phytoalexins. Ann. Rev. Phytopath. 10: 207-232.

Kuć, J., Currier, W.W. \& Shih, N.J. 1976. Terpenoid phytoalexins. In: Friend, J. \& Threlfall, D.R., Eds. Biochemical aspects of plant-parasite relationships. Ann. Proc. Phytochem. Soc. 13, Academic Press, NY, pp. 225-238.

KUĆ, J.K. \& Lisker, N. 1978. Terpenoids and their rôle in wounded and infected plant storage tissue. In: Kahl, G. Ed., Biochemistry of wounded plant tissues. Walter de Gruyter, NY, pp. 203-242.

Kuc, J. 1982. Phytoalexins from the Solanaceae. In: Bailey, J.A. \& Mansfield, J.W., Eds., Phytoalexins, Blackie, Glasgow and London, pp. 81-105.

Kuc, J., Tламos, E. \& Bostock, R. 1984. Metabolic regulation of terpenoid accumulation and disease resistance in potato. In: Nes, W.D., Fuller, G. \& Tsai, L.-S., Eds., Isopentenoids in plants - biochemistry and function, Marcel Dekker, NY, pp. 103-126.

Lindeberg, G. \& Lindeberg, M. 1974. Effect of short chain fatty acids on the growth of some mycorrhizal and saprophytic Hymenomycetes. Arch. Microbiol. 101: 109-114.

Lode, A. \& Pedersen, T.A. 1970. Fatty acid induced leaking of organic compounds from Boletus variegatus. Physiol. Plant. 23: 715-727.

Lyon, G.D., Lund, B.M., Bayliss, C.E. \& Wyatt, G.M. 1975. Resistance of potato tubers to Erwinia carotovora and formation of rishitin and phytuberin in infected tissue. Physiol. Plant Path. 6: 43-50.
Lyon, G.D. \& Bayluss, C.E. 1975: The effect of rishitin on Erwinia carotovora var. atroseptica and other bacteria. Physiol. Plant Path. 6: 177-186.

LYON, G.D. 1980. Evidence that the toxic effect of rishitin may be due to membrane damage. J. Experim. Botany 31: 957-966.

Macko, V., Staples, R.C., Renwick, J.A.A. \& Pirone, J. 1972. Germination self-inhibitors of rust uredospores. Physiol. Plant Pathol. 2: 347-355.

MACKo, V., 1983. Structural aspects of toxins. In: Daly, J.M. \& Deverall, B.J., Eds., Toxins and plant pathogenesis, Academic Press, NY, pp. 41-80.

Malmberg, A.G. \& Theander, O. 1980. Two phytoalexin glycosides from potato tubers infected with Phoma. Phytochemistry 19: 1739-1742.

Malmberg, A., Von Rosen, G., Schatz, B.-A. \& Thean. DER, O. 1980. Antifungal activity of phenolic compounds against Phoma exigua var. foveata in potato tubers. Swedish. J. Agic. Res. 10: 89-95.

Meyer, G. 1939. Zellphysiologische und Anatomische Untersuchungen über die Reaktion der Kartoffelknolle auf den Angriff der Phytophthora infestans bei Sorten Verschiedener Resistenz. Arb. Biol. Reichsanst. Landund Forstw. (Berlin) 23: 97-132.

Murai, A., Katsui, N., Yagihashi, F., Masamune, T., Ishigurı, Y. \& TomiYama, K. 1977. Structure of rishitinM-1 and M-2, metabolites of rishitin in healthy potato tuber tissues. J. Chem. Soc. Chem. Commun.: 670-671.

Moller, K.O. \& BOrger, H. 1940. Experimentelle Untersuchungen die Phytophthora-Resistenz der Kartoffel. Arb. Biol. Reichsanst. Land- und Forstw. (Berlin) 23: 189-231.

MOller, K.O. 1956. Einige einfache Versuche zum Nachsweis von Phytoalexinen. Phytopath. Z. 27: 237-254.

Neudecker, C. \& SChöber, B. 1984. Fütterungsversuche zum Teratogenen Potential Phytoalexinhaltiger Kartoffeln. EAPR Abstr. Conf. Papers: 372.

PAxton, J.D. 1981. Phytoalexins - a working redefinition. Phytopath. Z. 101: 106-109.

RAY, P.M.R. 1972. The living plant. 2nd ed., Holt, Rinehart and Winston, Inc., NY.

Reeve, R.M., Hautala, E. \& Weaver, M.L. 1969. Anatomy and composition within potatoes. Am. Potato J. 46: $361-386$.

RENWICK, J.H. 1972. Hypothesis: Anencephaly and bifida are usually preventably by avoidance of a specific but unidentified substance present in certain potato tubers. Brit. J. Prev. Soc. Med. 26: 67.

Rohwer, F., Fritzemeier, K.-H., Scheel, D. \& HahlвRоск, K. 1987. Biochemical reactions of different tissues of potato (Solanum tuberosum) to zoospores or elicitors from Phytophthora infestans. Accumulation of sesquiterpenoid phytoalexins. Planta 170: 556-561.

Rotecs, i.e. Registry of Toxic effects of Chemical Substances, 1980, Lewis, R.J., Sr. \& Tatken, R.L. (Editors), Cincinnati, Ohio, U.S.A. 
Sato, N., Kitazawa, K. \& Tomiyama, K. 1971. The rôle of rishitin in localizing the invading hyphae of Phytophthora infestans in infection sites at the cut surfaces of potato tubers. Physiol. Plant Path. 1: 289-295.

SCHÖBER, B. 1978. Content of phytoalexins in potato tuber tissue after infection with Phytophthora infestans (Mont.) de Bary. Abstr. Papers, 3rd Int. Congr. Plant Pathol.: 243.

SCHÖBer, B. 1980. Phytoalexine in Knollen resistenter und anfälliger Kartoffelsorten nach Infection mit Phytophthora infestans (Mont.) de Bary. Potato Res. 23: 435-443.

Schónbeck, F. \& Schlosser, E. 1976. Preformed substances as potential protectants. In: R. Heitefuss and P.H. Williams, Eds., Physiological plant pathology, Springer-Verlag, Berlin, Heidelberg, NY, pp. 653-678.

Sitte, P. 1974. Allgemeine Morphologie der Pflanzenzelle. In: Hirsch, G.C., Ruska, H. \& Sitte, P., Eds., Grundlagen der Cytologie, 2. Aufl., G. Fisher, Jena, pp. $391-412$.

Sмıтн, D.A. 1982. Toxicity of phytoalexins. In: Bailey, J.A. \& Mansfield, J.W., Eds., Phytoalexins, Blackie, Glasgow and London, pp. 218-252.

Stoesst, A., Stothers, J.B. \& W Wrd, E.W. 1976. Sesquiterpenoid stress compounds of the Solanaceae (review). Phytochemistry 15: 855-872.

Stoesst, A. 1980. Phytoalexins - a biogenetic perspective. Phytopath. Z. 99: 251-272.

Stoessı, A. 1982. Biosynthesis of phytoalexins. In: J.A. Bailey and J.A. Mansfield, Eds., Phytoalexins, Blackie, Glasgow and London, pp. 130-180.

\section{SELOSTUS}

\section{Perunan fytoaleksiinit: kriittinen tarkastelu}

\section{Sture Brishammar}

Department of Plant and Forest Protection, The Swedish University of Agricultural Sciences, P.O. Box 7044, S-750 07 Uppsala, Sweden

Perunan fytoaleksiinit ovat seskviterpeenejä, joita kertyy mukuloihin infektioiden seurauksena. Niiden on arveltu osittain säătelevän perunan taudinkestảvyyttä, joskin niitä muodostuu sekă alttiissa ettă keståvissă lajikkeissa. Fytoaleksiinien määrä riippuu mukuloiden fysiologisesta tilasta, nuorissa mukuloissa niită on hyvin vähăn. Koska monet patogeenit aiheuttavat samojen fytoaleksiinien muodostumisen, on todennăköistä, ettă jokin solunsisaainen elisitori laukaisee niiden tuotannon.

Sopivien testimenetelmien puuttuessa ei vielä tiedetă,
Stossel, P. \& Hонl, H.R. 1981. Effect of phytoalexins on hyphal growth and $\beta$-glucanases of Phytophthora infestans. Mycopathologia 73: 153-159.

Tagagi, Y., Fugimori, T., Kaneko, H. \& Kato, K. 1979. Phytuberol from Japanese domestic tobacco, Nicotiana tabacum cv. Suifu. Agric. Biol. Chem.: 2395-2396.

Tomiyama, K., Sakuma, T., Ishizaka, N., Sato, N., Katsui, N., Takasugi, M. \& Masamune, T. 1968. A new antifungal substance isolated from resistant potato tuber tissue infected by pathogens. Phytopathology 58: 115-116.

Van Der Plank, J.E. 1975. Principles of plant infection. Academic Press, NY.

Varns, J., Currier, W. \& Kuć, J. 1971. Specificity of rishitin and phytuberin accumulated by potato. Phytopathology 61: 968-971.

W AIN, R.L. 1977. Chemicals which control plant growth. Chem. Soc. Rev. 6: 261-275.

W ARd, E.W.B., Unwin, C.H. \& Stoesst, A. 1974. Postinfectional inhibitors from plants. XIII: Fungitoxicity of the phytoalexin, capsidiol, and related sesquiterpenes. Can. J. Bot. 52: 2481-2488.

W Ard, E.W.B., Stoessl, A. \& Stothers, J.B. 1977. Metabolism of the sesquiterpenoid phytoalexins capsidiol and rishitin to their 13-hydroxy derivatives by plant cells. Phytochemistry 16: 2024-2025.

WICKBERG, B. 1983. Kemisk Tidskrift 9: 6-8.

WIIson, C.L. 1973. A lysosomal concept for plant pathology. Ann. Rev. Phytopathol. 11: 247-272.

Ms received August 19, 1987 mihin fytoaleksiinien patogeenejả estävả vaikutus perustuu. Fytoaleksiineja puhdistettaessa saattaa syntyă artefakteja, jotka haittaavat joidenkin yhdisteiden tunnistusta. Nykyisiä analyysimenetelmiă onkin huomattavasti kehitetiaavă, ennen kuin voidaan selvittaa fytoaleksiinien vaikutusta in vivo. Todennăköisesti ne syntetoituvat kasvissa liian myöhään pystyäkseen estämäăn infektion leviämistä. Fytoaleksiinit eivät tiettảvästi ole terveydelle vaarallisia, ja niită kertyy vain mukuloiden infektoituneisiin osiin. 